\title{
Enrichment and characterization of ammonia- oxidizing archaea from the open ocean: phylogeny, physiology and stable isotope fractionation
}

\author{
Alyson E Santoro ${ }^{1}$ and Karen L Casciotti ${ }^{2}$ \\ Department of Marine Chemistry and Geochemistry, Woods Hole Oceanographic Institution, Woods Hole, \\ MA, USA
}

\begin{abstract}
Archaeal genes for ammonia oxidation are widespread in the marine environment, but direct physiological evidence for ammonia oxidation by marine archaea is limited. We report the enrichment and characterization of three strains of pelagic ammonia-oxidizing archaea (AOA) from the North Pacific Ocean that have been maintained in laboratory culture for over 3 years. Phylogenetic analyses indicate the three strains belong to a previously identified clade of water column-associated AOA and possess $16 \mathrm{~S}$ ribosomal RNA genes and ammonia monooxygenase subunit a $(a m o A)$ genes highly similar (98-99\% identity) to those recovered in DNA and complementary DNA clone libraries from the open ocean. The strains grow in natural seawaterbased liquid medium while stoichiometrically converting ammonia $\left(\mathrm{NH}_{3}\right)$ to nitrite $\left(\mathrm{NO}_{2}^{-}\right)$. Ammonia oxidation by the enrichments is only partially inhibited by allylthiourea at concentrations known to completely inhibit cultivated ammonia-oxidizing bacteria. The three strains were used to determine the nitrogen stable isotope effect $\left({ }^{15} \varepsilon_{\mathrm{NH} 3}\right)$ during archaeal ammonia oxidation, an important parameter for interpreting stable isotope ratios in the environment. Archaeal ${ }^{15} \varepsilon_{\mathrm{NH} 3}$ ranged from $13 \%$ to $41 \%$, within the range of that previously reported for ammonia-oxidizing bacteria. Despite low amino acid identity between the archaeal and bacterial Amo proteins, their functional diversity as captured by ${ }^{15} \varepsilon_{\mathrm{NH} 3}$ is similar.
\end{abstract}

The ISME Journal (2011) 5, 1796-1808; doi:10.1038/ismej.2011.58; published online 12 May 2011

Subject Category: geomicrobiology and microbial contributions to geochemical cycles

Keywords: thaumarchaea; nitrification; Pacific ocean; isotope effects

\section{Introduction}

Mesophilic archaea are ubiquitous and abundant members of diverse marine environments including coastal waters (Mincer et al., 2007; Beman et al., 2010), marine sediments, estuaries (Mosier and Francis, 2008; Bernhard et al., 2010; Urakawa et al., 2010), stratified basins (Coolen et al., 2007; Lam et al., 2007) and open ocean water columns (Beman et al., 2008; Church et al., 2010; Santoro et al., 2010). The recent cultivation of the first mesophilic marine archaeon, Nitrosopumilus maritimus, (Konneke et al., 2005; Martens-Habbena et al., 2009), two thermophilic archaea, Nitrosocaldus yellowstonii and Nitrosophaera gargensis

Correspondence: AE Santoro, Department of Marine Chemistry and Geochemistry, Woods Hole Oceanographic Institution, 360 Woods Hole Rd, M/S 52, Woods Hole, MA 02543, USA.

E-mail: asantoro@umces.edu

${ }^{1}$ Current address: Horn Point Laboratory, University of Maryland Center for Environmental Science, Cambridge, MD 21613, USA.

${ }^{2}$ Current address: Department of Environmental Earth System Science, Stanford University, Stanford, CA 94305, USA.

Received 1 December 2010; revised 16 March 2011; accepted 24 March 2011; published online 12 May 2011
(Hatzenpichler et al., 2008; de la Torre et al., 2008) and a freshwater archaeon, Nitrosoarchaeum limnia (Blainey et al., 2011) established that at least some of these organisms are chemolithoautotrophic ammonia oxidizers. Several studies coupling geneand cell-based quantification of putative ammoniaoxidizing archaea (AOA) to rate measurements (Wuchter et al., 2006; Beman et al., 2008; Santoro et al., 2010) suggest that nitrification by AOA in the ocean is significant. However, direct demonstration of ammonia-oxidizing activity by the AOA genotypes encountered in the open ocean has not yet been demonstrated.

Ammonia oxidation is the first step of nitrification, a key remineralization reaction in the sea. Work by Olson (1981) and Ward et al. (1982) using ${ }^{15} \mathrm{~N}$ tracers first suggested that nitrification in the upper ocean could be a significant source of regenerated nutrients for primary production. The quantitative role, however, of nitrification in the euphotic zone is still uncertain. Recent syntheses of nitrification rates made using isotope tracers (Yool et al., 2007; Clark et al., 2008) suggest that globally, nitrification may be a significant source of regenerated $\mathrm{N}$ for primary production, supplying as much 
as half of the necessary nitrate. This has important implications for estimates of carbon export based on new production (Eppley and Peterson, 1979); an underestimation of nutrient regeneration would lead to an overestimation of carbon export from the surface ocean (Ward, 2002).

Although instantaneous rate measurements with ${ }^{15} \mathrm{~N}$-labeled compounds provide important insights into the environmental controls on nitrification, they capture only a 'snapshot' view of this undoubtedly time-varying process. An alternative way of quantifying the importance of nitrification is using natural abundance stable isotope ratios to infer the relative importance of different nitrogen cycling processes. In particular, nitrogen and oxygen stable isotope ratios $\left(\delta^{15} \mathrm{~N}\right.$ and $\left.\delta^{18} \mathrm{O}\right)$ in marine nitrate $\left(\mathrm{NO}_{3}^{-}\right)$can integrate information about the relative sources (nitrification, upward diffusion, atmospheric deposition) and sinks (phytoplankton uptake) of $\mathrm{NO}_{3}^{-}$in the euphotic zone (Sigman et al., 2005; Wankel et al., 2007; Casciotti et al., 2008; DiFiore et al., 2009) and provide an independent constraint on the importance of nitrification to new production. In order to interpret these measurements, however, the isotope effects for the various sources and sinks of $\mathrm{NO}_{3}^{-}$must be known. The isotope effects for $\mathrm{NO}_{3}^{-}$uptake by phytoplankton (Needoba et al., 2003; Granger et al., 2004) and $\mathrm{NO}_{2}^{-}$ production by nitrifying bacteria (Mariotti et al., 1981; Casciotti et al., 2003, 2010) are relatively well studied, but there are no data on the isotope effects for ammonia oxidation by AOA.

In this study, we describe the enrichment and characterization of three strains of AOA from the water column of the North Eastern Pacific Ocean that oxidize $\mathrm{NH}_{3}$ to $\mathrm{NO}_{2}^{-}$. We used the three strains to estimate the nitrogen kinetic isotope effect $\left({ }^{15} \varepsilon_{\mathrm{NH}}\right)$ during ammonia oxidation by AOA. Our results extend the ability for chemoautotrophic ammonia oxidation within the Archaea and expand the number of marine archaea for which we have both phylogeny and confirmed metabolic function. We provide important constraints for the interpretation of natural abundance stable isotope ratios for compounds affected by these ubiquitous organisms in the marine nitrogen cycle.

\section{Materials and methods}

Enrichment and cultivation

Enrichment cultures were initiated with water collected from the North Eastern Pacific approximately $300 \mathrm{~km}$ from shore (California Cooperative Oceanic Fisheries Investigations station 67-90; $35.46^{\circ} \mathrm{N}, 124.91^{\circ} \mathrm{W}$ ) aboard the R/V Western Flyer during cruise CN107 in July 2007 (Table 1). Seawater was collected from 25, 75, 150 and $500 \mathrm{~m}$ depths using a standard $10 \mathrm{l}$ Niskin rosette sampler equipped with a conductivity-temperature-depth sensor package. Seawater was stored at $22^{\circ} \mathrm{C}$
Table 1 In situ conditions for the starting material for North Pacific Ocean seawater enrichments used for archaeal kinetic isotope fractionation $\left({ }^{15} \varepsilon_{\mathrm{NH} 3}\right)$ determination

\begin{tabular}{lcccc}
\hline Enrichment & $\begin{array}{c}\text { Depth } \\
(\mathrm{m})\end{array}$ & $\begin{array}{c}\mathrm{Temp} \\
\left.{ }^{\circ} \mathrm{C}\right)\end{array}$ & $\begin{array}{c}{\left[\mathrm{NH}_{4}^{+}\right]} \\
\left(\mathrm{nmol}^{-1}\right)\end{array}$ & $\begin{array}{c}{\left[\mathrm{NO}_{3}^{-}\right]} \\
\left(\mu \mathrm{mol}{ }^{-1}\right)\end{array}$ \\
\hline CN25 & 25 & 14 & 40 & 0.5 \\
CN75 & 75 & 12 & $<15$ & 2.2 \\
CN150 & 150 & 10 & $<15$ & 15.1 \\
\hline
\end{tabular}

(25 and $75 \mathrm{~m}$ waters) and $4{ }^{\circ} \mathrm{C}$ (150 and $500 \mathrm{~m}$ waters) in $500 \mathrm{ml}$ acid-cleaned polycarbonate bottles. After 20 months of incubation, filter sterile ammonium chloride $\left(\mathrm{NH}_{4} \mathrm{Cl}\right)$ was added to a final concentration of $10 \mu \mathrm{moll}^{-1}$ and the enrichments were monitored for production of $\mathrm{NO}_{2}^{-}$using standard colorimetric methods (Strickland and Parsons, 1968). At that time, the $150 \mathrm{~m}$ enrichment was moved to $13^{\circ} \mathrm{C}$ and maintained at that temperature. Hereafter, the successful enrichments are referred to as CN25, CN75 and CN150 referring to the cruise name and depth of the enrichment inoculums.

Cultures were maintained with transfers of $10-20 \%(\mathrm{v} / \mathrm{v})$ late exponential phase culture into oligotrophic North Pacific (ONP) medium consisting of: $0.2 \mu \mathrm{m}$-filtered North Pacific surface seawater amended with $10-100 \mu \mathrm{mol} \mathrm{l}^{-1} \mathrm{NH}_{4} \mathrm{Cl}, 1 \mathrm{ml} \mathrm{l}^{-1}$ chelated trace elements solution (Balch et al., 1979), $15 \mu \mathrm{mol} \mathrm{l}^{-1} \mathrm{KH}_{2} \mathrm{PO}_{4}$ and $100 \mu \mathrm{g} \mathrm{ml}^{-1}$ each streptomycin and ampicillin. Maintenance cultures were grown in $200 \mathrm{ml}$ volumes in $250 \mathrm{ml}$ acid-cleaned polycarbonate bottles. Surface seawater for ONP medium was obtained either from the initial collection site or from the Pacific hydrographic station SAFe (Johnson et al., 2007).

Abundance of archaeal and bacterial cells in the enrichments was periodically monitored in $1 \mathrm{ml}$ formaldehyde-fixed culture volumes filtered onto $25 \mathrm{~mm}$ diameter, $0.2 \mu \mathrm{m}$ pore size polycarbonate filters (Millipore GTTP, Billerica, MA, USA) with catalyzed auto reporter deposition-fluorescent in situ hybridization (CARD-FISH) and epifluorescence microscopy using probes Cren537-554 and EUB338 I-III (Teira et al., 2004).

Phylogenetic analysis of $16 S$ rRNA and amoA genes DNA was extracted and purified from $25 \mathrm{ml}$ of culture after vacuum filtration onto $25 \mathrm{~mm}$ diameter, $0.2 \mu \mathrm{m}$ pore size Supor membrane filters (Pall, Port Washington, NY, USA) using DNeasy columns (Qiagen, Valencia, CA, USA) as previously described (Santoro et al., 2008). Genes encoding for the $16 \mathrm{~S}$ ribosomal RNA (rRNA) and the $\alpha$ subunit of ammonia monooxygenase ( $a m o A)$, believed to contain the catalytic site for ammonia oxidation (Hyman and Wood, 1985), were amplified using PCR. Target genes were amplified in $25 \mu \mathrm{l}$ PCR reactions using the primers: 21F/1492R (archaeal 16S rRNA genes, DeLong, 1992), ArchamoAF/ArchamoAR 
(archaeal amoA, Francis et al., 2005), 27F/1492R (bacterial 16S rRNA) and amoAF*/amoAR (betaproteobacterial amoA, Stephen et al., 1999) using reaction and thermocycling conditions described in the original papers or as modified in Santoro et al., 2010. Gammaproteobacterial amo $A$ genes were amplified using the amoA3F/amoB4R primer set (Purkhold et al., 2000) using the following thermocycling profile: $95^{\circ} \mathrm{C}$ for $3 \mathrm{~min}$ followed by 35 cycles of: $95{ }^{\circ} \mathrm{C}$ for $30 \mathrm{~s}, 50{ }^{\circ} \mathrm{C}$ for $45 \mathrm{~s}$ and $72{ }^{\circ} \mathrm{C}$ for $1 \mathrm{~min}$. Genomic DNA from Nitrosococcus oceani was used as a positive control. PCR products were pooled, purified (MinElute PCR Purification Kit, Qiagen), and cloned using the TOPO-TA cloning kit with pCR4 vector and MACH1 competent cells (Invitrogen, Carlsbad, CA, USA). Plasmids were purified (Mini Prep Spin Kit, Qiagen) and sequenced on an ABI 3730xl sequencer. Twelve archaeal 16S rRNA and amoA clones and 24 bacterial 16S rRNA clones were sequenced per enrichment.

16S rRNA gene sequences were imported into the ARB software program (Ludwig et al., 2004) and aligned to a subset of the SILVA SSU reference database, February 2009 release (Pruesse et al., 2007). Archaeal amo $A$ sequences were manually aligned and imported into an ARB database maintained by our laboratory containing approximately 2000 environmental amoA sequences. Phylogenetic trees were constructed using 1268 nucleotide positions (16S rRNA) or 489 nucleotide positions (amoA) using maximum likelihood (RAxML) analyses implemented using the Cyberinfrastructure for Phylogenetic Research (CIPRES) Portal v3.0 (www. phylo.org) and visualized using FigTree v1.3.1 (http://tree.bio.ed.ac.uk/software/figtree/). Archaeal $16 \mathrm{~S}$ rRNA gene and amo $A$ sequences from this study were deposited in GenBank under the accession numbers HQ338108-HQ338109 and JF521547JF521549.

\section{Growth curves}

Growth curves were determined for CN25 and CN75 at $22{ }^{\circ} \mathrm{C}$ in replicate $200 \mathrm{ml}$ volumes of ONP medium containing $50 \mu \mathrm{moll}^{-1} \mathrm{NH}_{4}^{+}$. At each time point, $15 \mathrm{ml}$ of culture was removed. Ten milliliters of culture were frozen for later $\left[\mathrm{NO}_{2}^{-}\right]$and $\left[\mathrm{NH}_{4}^{+}\right]$ determination. The remaining $5 \mathrm{ml}$ of culture were immediately fixed with formaldehyde $(2 \%$ final concentration) for four hours and replicate volumes $(0.5-2 \mathrm{ml})$ of fixed culture were vacuum filtered onto $25 \mathrm{~mm}, 0.2 \mu \mathrm{m}$ pore size polycarbonate membrane filters (Millipore) and frozen for later CARDFISH analysis as described above. A minimum of 10 fields of view were counted from each filter using the $100 \times$ objective on a Zeiss Axio Scope (Carl Zeiss, Jena, Germany) epifluorescence microscope. $\left[\mathrm{NH}_{4}^{+}\right]$and $\left[\mathrm{NO}_{2}^{-}\right]$determinations were made in duplicate using phthaldialdehyde fluorescence (Holmes et al., 1999) and azo dye colorimetry (Strickland and Parsons, 1968), respectively.

\section{Allylthiourea inhibition experiments}

To assess the effect of the metal chelator allylthiourea (ATU) on archaeal ammonia oxidation, strain CN25 was grown in triplicate $50 \mathrm{ml}$ volumes in $60 \mathrm{ml}$ polycarbonate screw cap bottles for each of three treatments: no ATU addition (control), $10 \mathrm{mg} \mathrm{l}^{-1}$ ATU $\left(86 \mu \mathrm{mol} \mathrm{l}^{-1}\right)$, and $100 \mathrm{mg} \mathrm{l}^{-1}\left(860 \mu \mathrm{mol} \mathrm{l}^{-1}\right)$. ATU additions were made from a $10 \mathrm{mg} \mathrm{ml}^{-1}$ stock solution of ATU (Sigma) dissolved in water. Ammonia oxidation was monitored by the production of $\mathrm{NO}_{2}^{-}$, determined using azo dye colorimetry in $1 \mathrm{ml}$ volumes (Strickland and Parsons, 1968). ATU was added to the treatment bottles after initial $\mathrm{NO}_{2}^{-}$ production was detected in each flask (day 4). Inhibition for the ATU treatments was calculated as the percent decrease in slope of a linear regression fit to the $\ln \left[\mathrm{NO}_{2}^{-}\right]$over time compared with the control bottles.

\section{Nitrogen isotope effect estimates}

For each experiment, $25 \mathrm{ml}$ of enrichment culture was inoculated into $175 \mathrm{ml}$ of ONP medium containing $10-75 \mu \mathrm{mol} \mathrm{l}^{-1} \mathrm{NH}_{4}^{+}$in a $250 \mathrm{ml}$ acid-washed, screwcap polycarbonate bottle. Growth was not observed when experiments were initiated with washed cell suspensions collected by filtration (data not shown), thus all experiments started with an initial $\left[\mathrm{NO}_{2}^{-}\right]$ between 2 and $10 \mu \mathrm{moll}^{-1}$ as well as residual $\mathrm{NH}_{4}^{+}$ from maintenance cultures, in some cases. Temperature was maintained at $22^{\circ} \mathrm{C}$ for CN25 and CN75 and $13{ }^{\circ} \mathrm{C}$ for $\mathrm{CN} 150 . \mathrm{NO}_{2}^{-}$production was monitored and $15 \mathrm{ml}$ of enrichment culture was removed at each time point and frozen at $-20^{\circ} \mathrm{C}$.

Initial and time-course measurements of $\left[\mathrm{NH}_{4}^{+}\right]$ and $\left[\mathrm{NO}_{2}^{-}\right]$were made in duplicate using phthaldialdehyde fluorescence (Holmes et al., 1999) and azo dye colorimetry (Strickland and Parsons, 1968), respectively, on $2 \mathrm{ml}$ sample volumes. Error in replicate $\left[\mathrm{NH}_{4}^{+}\right]$analyses ranged from $2 \%$ to $7 \%$; error in replicate $\left[\mathrm{NO}_{2}^{-}\right]$analyses was $0 \%$ to $8 \%$. Isotopic measurements of $\mathrm{NO}_{2}^{-}$were made by converting $\mathrm{NO}_{2}^{-}$to nitrous oxide $\left(\mathrm{N}_{2} \mathrm{O}\right)$ using the 'azide method' (McIlvin and Altabet, 2005) with $10-20 \mathrm{nmol} N$ per sample. The resulting $\mathrm{N}_{2} \mathrm{O}$ was captured using a custom purge and cryogenic trapping system (Casciotti et al., 2002; McIlvin and Casciotti, 2010, 2011) and analyzed using a Finnigan

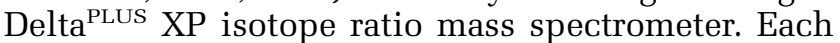
sample was analyzed in duplicate against RSIL nitrite reference materials N23, N7373 and N10219 run in parallel (Casciotti et al., 2007). Results are reported using delta notation: $\delta^{15} \mathrm{~N}_{\mathrm{NO} 2}$ (\%ovs AIR) $=$ $\left[\left({ }^{15} \mathrm{R}_{\mathrm{NO} 2} /{ }^{15} \mathrm{R}_{\mathrm{AIR}}\right)-1\right] \times 1000$, where ${ }^{15} \mathrm{R}={ }^{15} \mathrm{~N}:{ }^{14} \mathrm{~N}$ and AIR is standard atmospheric $\mathrm{N}_{2}$. Error in replicate measurements of $\delta^{15} \mathrm{~N}_{\mathrm{NO} 2}$ was $0.3 \%$ or better for all experiments.

Calculation of ${ }^{15} \varepsilon_{\mathrm{NH} 3}$ requires knowledge of the isotopic composition of the $\mathrm{NO}_{2}^{-}$produced over time since an arbitrary starting point. If the initial $\left[\mathrm{NO}_{2}^{-}\right]$ is zero, then the measured $\delta^{15} \mathrm{~N}_{\mathrm{NO} 2}\left(\delta^{15} \mathrm{~N}_{\mathrm{NO} 2 \text { total }}\right)$ is 
equal to that produced $\left(\delta^{15} \mathrm{~N}_{\mathrm{NO} \text { 2produced }}\right)$. If there is $\mathrm{NO}_{2}^{-}$initially present, as in our experiments, the $\delta^{15} \mathrm{~N}_{\mathrm{NO} 2 \text { produced }}$ at any time since the initial time point (i) must be calculated from $\delta^{15} \mathrm{~N}_{\mathrm{NO} 2 \text { total }}$ using the following equations:

$$
\begin{aligned}
& \left({ }^{15} \mathrm{~N}:{ }^{14} \mathrm{~N}\right)_{\text {total }} \times\left[\mathrm{NO}_{2}^{-}\right]_{\text {total }} \\
& =\left({ }^{15} \mathrm{~N}:{ }^{14} \mathrm{~N}\right)_{\text {produced }} \times\left[\mathrm{NO}_{2}^{-}\right]_{\text {produced }} \\
& \quad+\left({ }^{15} \mathrm{~N}:{ }^{14} \mathrm{~N}\right)_{i} \times\left[\mathrm{NO}_{2}^{-}\right]_{i}
\end{aligned}
$$

where $\left({ }^{15} \mathrm{~N}:{ }^{14} \mathrm{~N}\right)_{\text {total }}=\left({ }^{15} \mathrm{~N}:{ }^{14} \mathrm{~N}\right)_{\mathrm{AIR}} \times\left(\delta^{15} \mathrm{~N}_{\mathrm{NO} 2 \text { total }} / 1000+1\right)$ Rearranging:

$$
\begin{aligned}
&\left({ }^{15} \mathrm{~N}:{ }^{14} \mathrm{~N}\right)_{\text {produced }} \\
&=\left\{\left({ }^{15} \mathrm{~N}:{ }^{14} \mathrm{~N}\right)_{\text {total }} \times\left[\mathrm{NO}_{2}^{-}\right]_{\text {total }}\right. \\
&\left.-\left({ }^{15} \mathrm{~N}:{ }^{14} \mathrm{~N}\right)_{i} \times\left[\mathrm{NO}_{2}^{-}\right]_{i}\right\} /\left[\mathrm{NO}_{2}^{-}\right]_{\text {produced }} \\
& \delta^{15} \mathrm{~N}_{\mathrm{NO}_{2}} \text { produced }=\left[\left({ }^{15} \mathrm{~N}:{ }^{14} \mathrm{~N}\right)_{\text {produced }} /\left({ }^{15} \mathrm{~N}:{ }^{14} \mathrm{~N}\right)_{\mathrm{AIR}}-1\right] \times 1000
\end{aligned}
$$

The isotope effect $\left({ }^{15} \varepsilon_{\mathrm{NH} 3}\right)$ was then calculated from the $\delta^{15} \mathrm{~N}_{\mathrm{NO} 2 \text { produced }}$ data using the Rayleigh accumulated product equation (after Mariotti et al., 1981):

$$
\delta^{15} \mathrm{~N}_{\mathrm{NO}_{2 \text { produced }}}=\delta^{15} \mathrm{~N}_{\mathrm{NH}_{4 \text { initial }}}+{ }^{15} \varepsilon_{\mathrm{NH} 3}\left(\frac{f \ln (f)}{1-f}\right)
$$

where $f=\left[\mathrm{NH}_{4}^{+}\right] /\left[\mathrm{NH}_{4}^{+}\right]_{\text {initial }}$. By Eqn (3), the slope of a best fit line on a plot of $\delta^{15} \mathrm{~N}_{\mathrm{NO} 2}$ vs $f{ }^{*} \ln (f) /(1-f)$ yields ${ }^{15} \varepsilon_{\mathrm{NH} 3}$ and the $y$ intercept corresponds to the starting $\delta^{15} \mathrm{~N}_{\mathrm{NH} 4}$. As each experiment was initiated with a mixture of $\mathrm{NH}_{4}^{+}$carried over from the enrichment transfer and 'new' $\mathrm{NH}_{4}^{+}$from freshly prepared medium $\left(\delta^{15} \mathrm{~N} \sim-3 \%\right.$ ), minor variations in the $\delta^{15} \mathrm{~N}_{\mathrm{NH} 4}$ (and the $y$ intercept) are expected between experiments and therefore each experiment was fitted separately. Fitting and 95\% confidence interval calculations were done using IGOR Pro software (v5, WaveMetrics, Inc., Lake Oswego, OR, USA).

Use of the Rayleigh model presumes that ammonia oxidation proceeds as a pseudo one-step reaction with no accumulation of an intermediate product between $\mathrm{NH}_{3}$ and $\mathrm{NO}_{2}^{-}$and no back-reaction of the products (Casciotti et al., 2003). When estimated in this way, several isotope effects are incorporated into ${ }^{15} \varepsilon_{\mathrm{NH} 3}$ including a $\sim 20-35 \%$ equilibrium isotope effect between $\mathrm{NH}_{4}^{+}$and $\mathrm{NH}_{3}$ (Casciotti et al., 2011), as well as any isotope effects for $\mathrm{NH}_{3}$ or $\mathrm{NH}_{4}^{+}$diffusion. Errors in ${ }^{15} \varepsilon_{\mathrm{NH}}$ resulting from these assumptions, as well as errors resulting from uncertainties in the archaeal ammonia oxidation pathway, are discussed below.

\section{Results}

Phylogeny and physiology

Following 20 months of incubation in the dark with no amendments, archaeal amo $A$ genes were detected by PCR in all four seawater 'enrichment' bottles $(25,75,150$ and $500 \mathrm{~m})$. On addition of $10 \mu \mathrm{mol} \mathrm{l}{ }^{-1} \mathrm{NH}_{4}^{+}, \mathrm{NO}_{2}^{-}$production was observed in the enrichments from 25, 75 and $150 \mathrm{~m}$ within 1 month (data not shown). No $\mathrm{NO}_{2}^{-}$production was observed in the $500 \mathrm{~m}$ bottle. The $\mathrm{NO}_{2}^{-}$producing enrichments are referred to as CN25, CN75 and CN150. All three CN enrichments contained a high proportion of cells hybridizing with the CARD-FISH probe suite CREN537-554 and PCR amplifiable archaeal $a m o A$ genes. No $a m o A$ genes from either gamma or betaproteobacteria were detected.

After approximately 1 year of routine transfers into ONP medium (nearly 3 years after initial collection), the enrichments were highly enriched in archaeal cells (Figure 1) and the basic phylogeny and physiology of the enrichments were characterized. A consensus archaeal 16S rRNA gene sequence was obtained from 12 clones from each enrichment. One sequence from CN25 and two sequences from CN75 contained single nucleotide changes (all at different positions) from this consensus sequence.
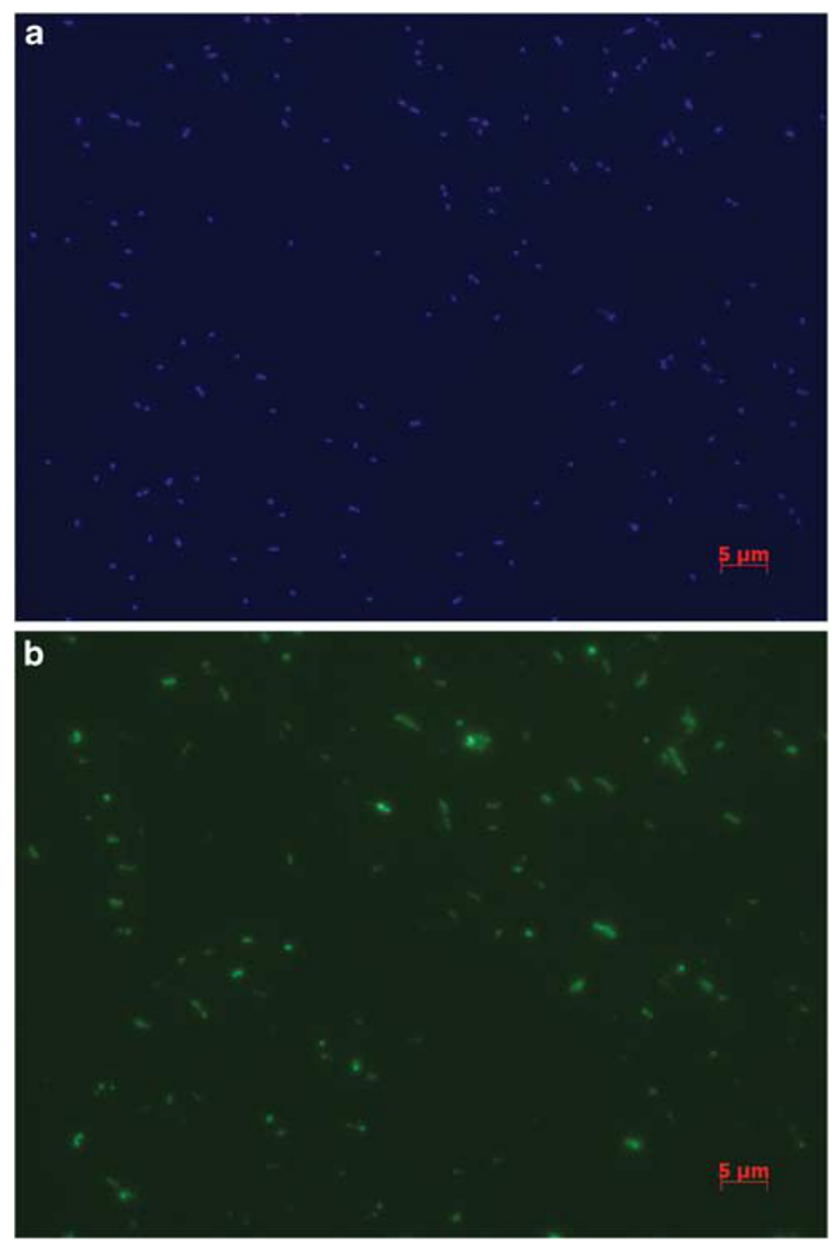

Figure 1 Fluorescence microscopy images of enrichment CN25 stained with (a) 4,6-diamidino-2-phenylindole (DAPI) and (b) CARD-FISH using the Cren537-554 probe suite. Both images are from the same field of view; the scale bar represents $5 \mu \mathrm{m}$. 
Phylogenetic analyses place all three sequences within the Marine Group I archaea, now proposed as a new archaeal kingdom-the Thaumarchaeota (Brochier-Armanet et al., 2008; Spang et al., 2010; Walker et al., 2010) (Figure 2a). The 16S rRNA gene sequences from CN25 and CN75 are 100\% identical to each other, and $92 \%$ identical to $N$. maritimus. Closest GenBank BLAST matches to the CN25 16S rRNA gene sequence are $98 \%$ identical and include sequences from environmental clone libraries from $200 \mathrm{~m}$ depth off the Oregon coast (fosmid 4B7, U40238, (Stein et al., 1996)) and an unpublished deep sea hydrothermal vent clone from Suiyo Seamount (AB194001). The CN150 16S rRNA gene is $98 \%$ identical to $N$. maritimus and $99 \%$ identical to several sequences from the Sargasso Sea metagenome (AACY020033564, (Venter et al., 2004)).

The amoA sequences from CN25 and CN75 fall within a cluster of environmental sequences previously termed water column cluster 'A'. They are also $100 \%$ identical at the amino acid level to several sequences from the Sargasso Sea metagenome (Venter et al., 2004) (Figure 2b, Supplementary Figure 1) and $84 \%$ and $95 \%$ identical at the nucleotide and amino acid levels, respectively, to the amo $A$ sequence from $N$. maritimus. The CN150 amo $A$ gene is also $84 \%$ identical to $N$. maritimus at the nucleic acid level. As CN25 and CN75 are identical at the 16S rRNA and amoA level, full genome sequencing may be necessary to resolve any strainlevel differences between the two enrichments.

Bacterial 16S rRNA gene clone libraries from the CN enrichments did not contain 16S rRNA genes from any genera of known bacterial nitrifiers and contained sequences associated with the genera Erythrobacter and Gracilimonas. Bacterial amoA genes could not be detected using PCR amplification.

Stoichiometric conversion of $\mathrm{NH}_{4}^{+}$to $\mathrm{NO}_{2}^{-}$was observed in all three enrichments coincident with an exponential increase in the number of archaeal cells, evidence that the $\mathrm{CN}$ strains couple ammonia oxidation to growth (Figure 3). All three CN strains were able to utilize $\mathrm{NH}_{4}^{+}$from the medium below our detection limit of $\sim 200 \mathrm{nM}$. Bacterial cells, as quantified by CARD-FISH, were not detectible until the archaeal population entered late exponentialearly stationary phase. CN25 and CN75, growing at $22{ }^{\circ} \mathrm{C}$, had lag phases of 4-10 days on transferring $10-25 \%$ of the original culture volume into new medium, even when cultures were transferred during exponential phase growth. Transfer volumes of $<10 \%$ failed to grow (data not shown). CN150, growing at $13{ }^{\circ} \mathrm{C}$, had lag phases of up to 25 days.

CN25 and CN75 were chosen for more detailed growth studies because of faster $\mathrm{NH}_{4}^{+}$oxidation rates, shorter lag phases, and more consistent growth. The CN25 growth rate at $22^{\circ} \mathrm{C}$ was 0.15 day $^{-1}$; the CN75 growth rate was 0.17 day $^{-1}$, corresponding to doubling times of about 4-4.6 days. Stationary phase cell densities in CN25 and CN75 were $2.7-3.2 \times 10^{6}$ cells ml ${ }^{-1}$ with $86-97 \%$ of cells hybridizing with archaeal CARD-FISH probes depending on the growth stage of the enrichment.

ATU is frequently used to inhibit nitrifying activity in environmental studies. We tested the effect of ATU on the ammonia oxidation rate for CN25. An ATU concentration of $10 \mathrm{mgl}^{-1}\left(86 \mu \mathrm{moll}^{-1}\right)$ inhibited the ammonia oxidation rate by $58 \%$; an ATU concentration of $100 \mathrm{mg} \mathrm{l}^{-1}\left(860 \mu \mathrm{mol} \mathrm{l}^{-1}\right)$ completely inhibited ammonia oxidation (Figure 4).

\section{Nitrogen isotopic fractionation}

To further investigate the physiology of the enriched strains, we determined their $\mathrm{N}$ kinetic isotope effect during ammonia oxidation $\left({ }^{15} \varepsilon_{\mathrm{NH} 3}\right)$. As in growth curve experiments, we observed near stoichiometric conversion of $\mathrm{NH}_{4}^{+}$to $\mathrm{NO}_{2}^{-}$over the course of the isotope fractionation experiments, with conservation in the dissolved inorganic nitrogen pool $\left(\mathrm{NH}_{4}^{+}+\mathrm{NO}_{2}^{-}\right)$ranging from $74 \%$ to $107 \%$ with a mean of $97 \%$ (Table 2).

Results from replicate experiments are reported individually, as well as an unweighted average of experiments for a given enrichment (Table 2). ${ }^{15} \varepsilon_{\mathrm{NH} 3}$ for CN25 ranged from 14 to $30 \%$ with an average of $22 \pm 5 \%$ o $(n=11),{ }^{15} \varepsilon_{\mathrm{NH} 3}$ for CN75 ranged from 10 to $37 \%$ with an average of $21 \pm 10 \%(n=6)$, and ${ }^{15} \varepsilon_{\mathrm{NH} 3}$ for CN150 ranged from 16 to $28 \%$ with an average of $22 \pm 5 \%(n=7)$. Non-linearity was observed in most experiments with CN25 and CN75, with larger ${ }^{15} \varepsilon_{\mathrm{NH} 3}$ (that is, greater slopes) at the beginning of the growth curve when a large fraction $(f)$ of the initial $\mathrm{NH}_{4}^{+}$remained (Figures 5a and b). This leads to large uncertainties (expressed as 95\% confidence intervals) in the slopes for many of the experiments with CN25 and CN75 (Table 2). We did not observe the same non-linearity of ${ }^{15} \varepsilon_{\mathrm{NH} 3}$ in experiments with CN150 (Figure 5c).

\section{Discussion}

Phylogeny

We established three enrichments of marine archaea that stoichiometrically oxidize $\mathrm{NH}_{4}^{+}$to $\mathrm{NO}_{2}^{-}$. Multiple lines of evidence suggest that the archaea are the active ammonia oxidizers in the enrichments. Archaeal cells increase exponentially concomitant with an exponential increase in $\mathrm{NO}_{2}^{-}$, and amoA genes from the enrichments have a high identity to known archaeal ammonia oxidizers. The enrichments lack $16 \mathrm{~S}$ rRNA and $a m o A$ genes associated with known $\gamma$ - or $\beta$-proteobacterial ammonia oxidizers. Though no $\mathrm{NO}_{2}^{-}$or $\mathrm{NO}_{3}^{-}$production was observed in the enrichment from $500 \mathrm{~m}$, this cannot be used to infer a lack of $\mathrm{NH}_{3}$-oxidizing ability in field populations at this depth, as active $\mathrm{NH}_{3}$ oxidation was measured in situ (Santoro et al., 2010).

Both 16S rRNA and amo $A$ gene sequences from the CN strains suggest they are representative of organisms present and active in the open ocean. 


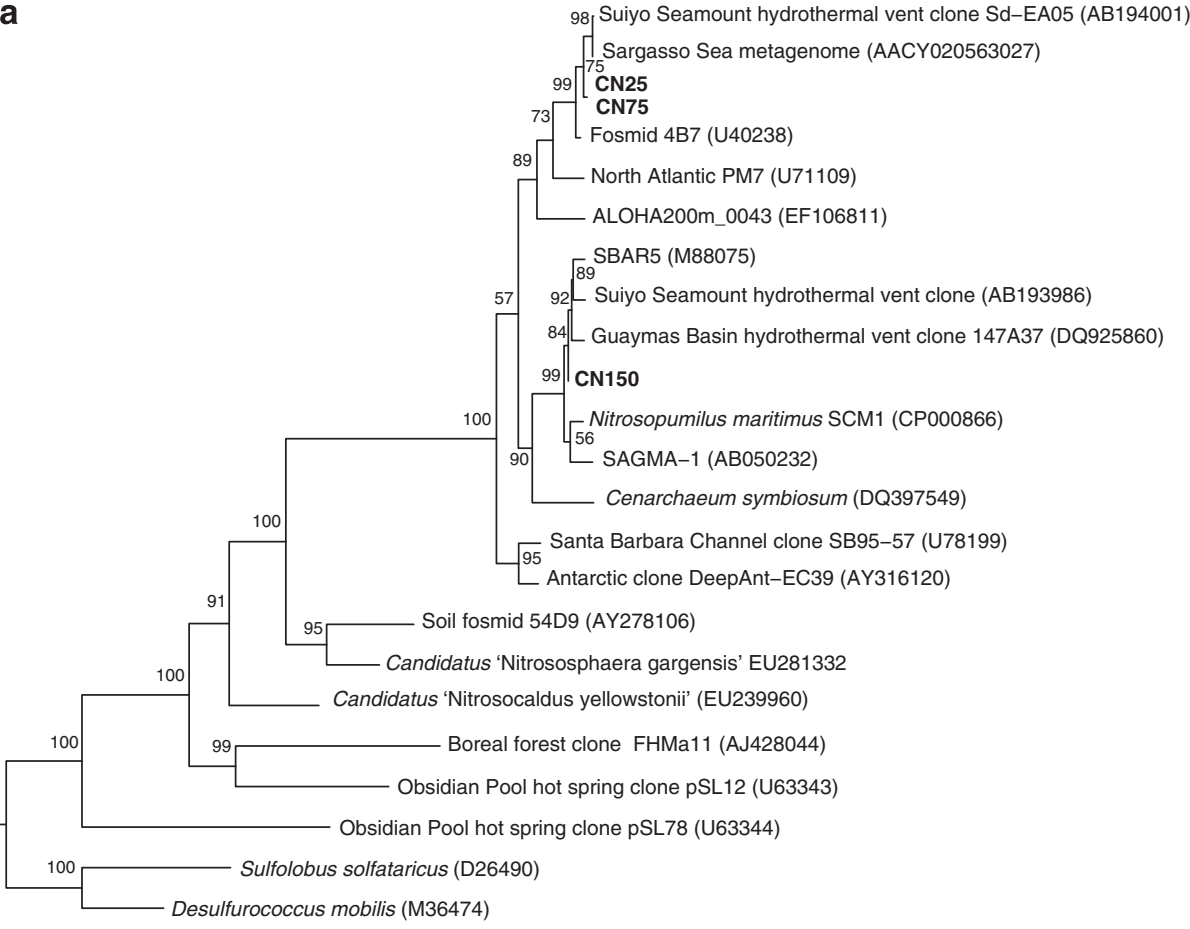

98 Suiyo Seamount hydrothermal vent clone Sd-EA05 (AB194001)

Sargasso Sea metagenome (AACY020563027)

[ Fosmid 4B7 (U40238)

North Atlantic PM7 (U71109)

A200m 0043 (EF106811)

Nitrosopumilus maritimus SCM1 (CP000866)

SAGMA-1 (AB050232)

Cenarchaeum symbiosum (DQ397549)

Santa Barbara Channel clone SB95-57 (U78199)

Antarctic clone DeepAnt-EC39 (AY316120)

0.1

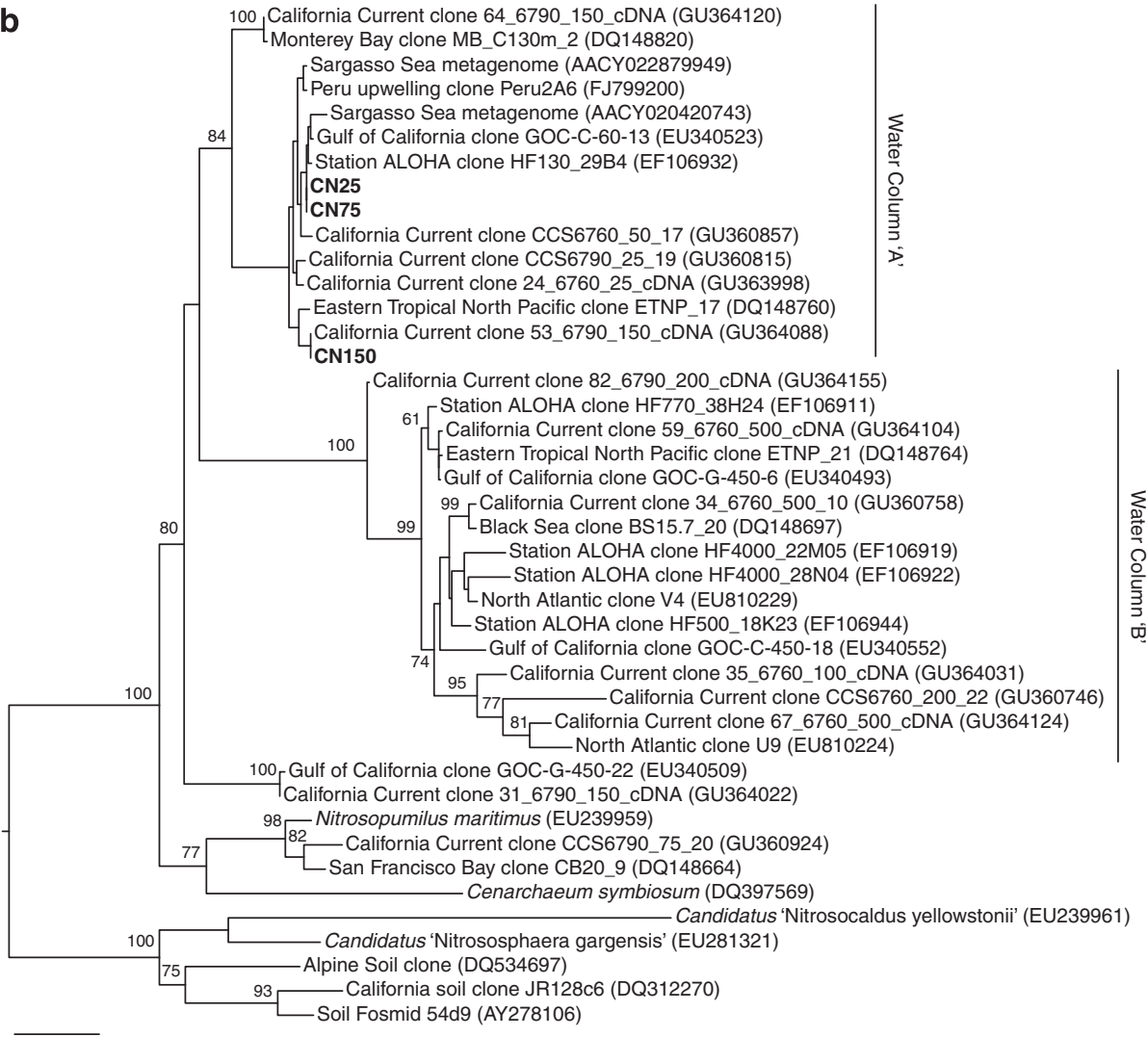

0.1

Figure 2 Phylogenetic placement of the CN enrichments based on (a) 16S rRNA gene sequences (1268 nucleotide positions) and (b) amo $A$ gene sequences (489 nucleic acid positions). The CN enrichment sequences are shown in bold. Trees were constructed using maximum likelihood methods (RAxML) using Sulfolobus solfataricus as the outgroup for the 16S rRNA tree and the soil and hot spring sequences as the outgroup for the amoA tree. Bootstrap support values ( $>70 \%$ ) are shown at nodes; some values have been removed from minor nodes for clarity. An expanded $a m o A$ tree with additional sequences from the study environment is included as Supplementary Figure 1. 
1802

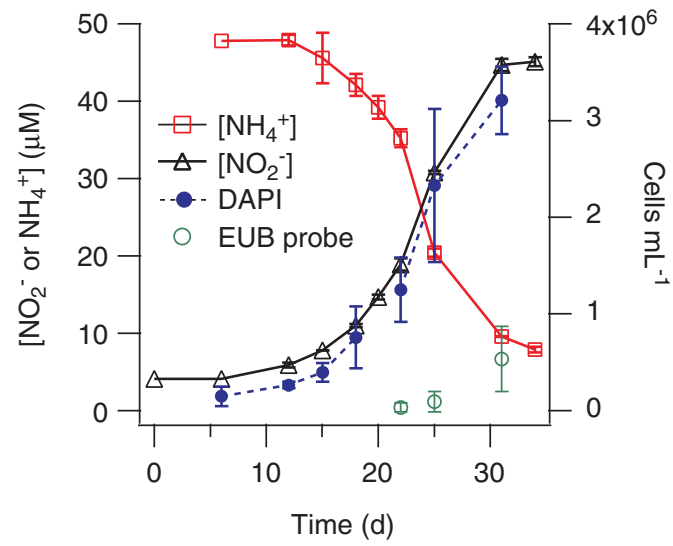

Figure 3 Growth of enrichment CN75 in ONP medium. Error bars denote 1 s.d. and in some cases are smaller than the point. EUB is the CARD-FISH probe suite EUB338 targeting all bacteria.

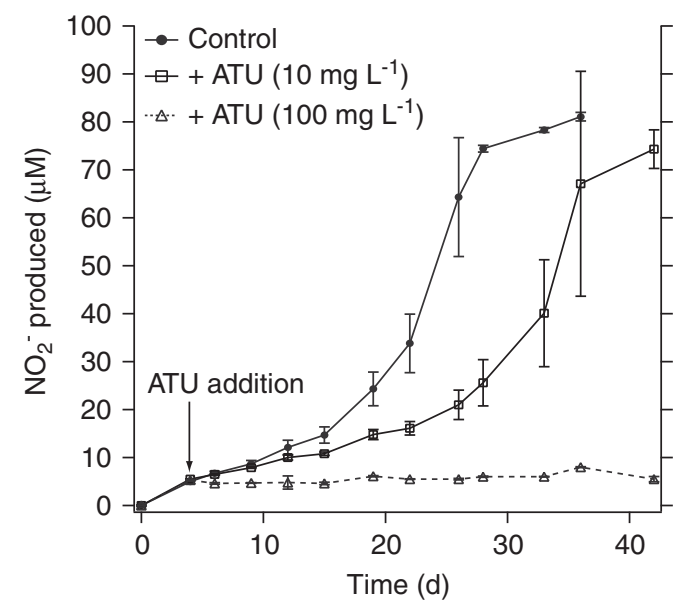

Figure 4 Ammonia oxidation by CN25 in the presence of 10 and $100 \mathrm{mg} \mathrm{l}^{-1}$ ATU. Each point represents the mean of three replicate bottles; error bars denote 1 s.d. from the mean.

CN25 and CN75 are 97\% identical to amoA sequences obtained in DNA-based clone libraries from the environment from which they were enriched (GU360825, (Santoro et al., 2010)) and $\mathrm{CN} 150$ is $100 \%$ identical to an amoA actively expressed in the environment (GU364088). The CN strains are also highly similar on the $16 \mathrm{~S}$ and amo $A$ level to abundant groups of open ocean archaea from a range of oceanic provinces including the Sargasso Sea, Fernandina Island and the coast of Africa as indicated by BLAST searches of the Global Ocean Survey dataset (Rusch et al., 2007). Previous amoAbased phylogenies of AOA have shown that water column-derived sequences fall into two clusters termed 'A' and 'B' (Francis et al., 2005) thought to represent a depth-dependent partitioning of AOA (Hallam et al., 2006; Mincer et al., 2007; Beman et al., 2008). The exact physiological basis for the partitioning of archaeal amo $A$ genotypes is unknown, but could include adaptations to temperature, light or substrate availability. Based on amo $A$ sequences, all three $\mathrm{CN}$ strains belong to the shallow water column clade 'A'. Our data now associate a 16S rRNA genotype with at least some members of the clade ' $A$ ' archaea that are distinct from $N$. maritimus and are likely to represent a new genus within the Thaumarchaea.

\section{Physiology}

The growth rate of CN25 and CN75 $\left(0.17\right.$ day $\left.^{-1}\right)$ in ONP medium is slower than growth rates reported for the cultivated AOA $N$. maritimus $\left(0.65\right.$ day $^{-1}$ at $30{ }^{\circ} \mathrm{C}$, (Martens-Habbena et al., 2009) and N. yellowstonii (0.8 day $^{-1}$ at $72{ }^{\circ} \mathrm{C}$, (de la Torre et al., 2008) and cultivated marine ammonia-oxidizing bacteria (AOB) (0.34-0.77 day $^{-1}$, (Prosser, 1990). These differences can be partially explained by the lower cultivation temperature of the $\mathrm{CN}$ enrichments $\left(22^{\circ} \mathrm{C}\right)$ relative to $N$. maritimus and $N$. yellowstonii. Further optimization of the culture medium may lead to increases in the growth rates reported here. The per-cell ammonia oxidation rate for the $\mathrm{CN}$ strains, $\sim 2 \mathrm{fmol} \mathrm{NO}_{2}^{-}$cell $^{-1}$ day $_{,}^{-1}$ is lower than N. maritimus (13 fmol cell ${ }^{-1}$ day $^{-1}$, (Martens-Habbena et al., 2009)), but similar to a mesocosm enrichment of archaea from North Atlantic (2-4 fmol cell ${ }^{-1}$ day $^{-1}$ )(Wuchter et al., 2006), and estimates of in situ per-cell activity rates in the California Current (0.2-15 fmol cell ${ }^{-1} \mathrm{day}^{-1}$ ) (Santoro et al., 2010).

Multiple isolation strategies, including the addition of antibiotics and size fractionation through $0.45 \mu \mathrm{m}$ filters, did not yield pure cultures of any of the CN strains. Dilution-to-extinction approaches were also not successful, as high dilutions of the CN strains did not grow (data not shown). N. yellowstonii and $N$. gargensis, the two cultivated thermophilic strains of AOA, also could not be established in pure culture (Hatzenpichler et al., 2008; de la Torre et al., 2008). This may be because there is a cooperative relationship between the bacteria and the archaea in these enrichment cultures, as has been reported in cultures of the marine chlorophyte Prochlorococcus (Morris et al., 2008), and low cell density dilutions that do not contain the associated heterotrophic bacteria are unable to grow. Interactions between the heterotrophic bacteria and autotrophic archaea in the enrichment, and in the ocean, will be an exciting area of future research.

We observed partial inhibition of archaeal ammonia-oxidizing activity by ATU at $86 \mu \mathrm{moll}^{-1}$, a concentration known to completely inhibit cultivated AOB (Hooper and Terry, 1973) and bacteriarich environmental samples (Ginestet et al., 1998). Near complete inhibition of ammonia oxidation in CN25 was observed at $860 \mu \mathrm{moll}^{-1}$ ATU. The mechanism of ATU inhibition in AOB is thought to be chelation of the $\mathrm{Cu}$ active site in the Amo protein (Bedard and Knowles, 1989). Our results are consistent with observations of $N$. gargensis (Hatzenpichler et al., 2008) and support the idea that ATU-inhibited nitrification rates may represent conservative estimates of AOA-only activity in the field. 
Table 2 Experimental results for kinetic isotope effect $\left({ }^{15} \varepsilon_{\mathrm{NH} 3}\right)$ determinations during of archaeal ammonia oxidation

\begin{tabular}{|c|c|c|c|c|c|c|}
\hline Enrichment & Experiment \# & $\begin{array}{l}{ }^{15} \varepsilon_{N H 3} \\
(\% 0)\end{array}$ & $\begin{array}{c}\text { CI } 95 \% \\
(\% 0)\end{array}$ & $\begin{array}{l}\text { Initial }\left[\mathrm{NH}_{4}^{+}\right] \\
\left(\mu \mathrm{moll} 1^{-1}\right)\end{array}$ & $\begin{array}{l}{[N+N]_{\text {final }}:} \\
{[N+N]_{\text {initial }}}\end{array}$ & 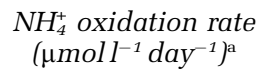 \\
\hline \multirow[t]{12}{*}{ CN25 } & 1 & 25 & 1 & 15 & 1.05 & 3.0 \\
\hline & & 28 & 28 & 15 & 1.05 & 2.5 \\
\hline & & 30 & 83 & 15 & 1.05 & 2.1 \\
\hline & 2 & 25 & 52 & 9 & 0.99 & 0.4 \\
\hline & 3 & 26 & 21 & 16 & 0.74 & 0.8 \\
\hline & & 14 & 4 & 16 & 0.98 & 0.9 \\
\hline & & 15 & 3 & 14 & 1.07 & 0.4 \\
\hline & 4 & 20 & 7 & 76 & 1.03 & 4.5 \\
\hline & & 21 & 6 & 77 & 1.02 & 4.5 \\
\hline & & 20 & 4 & 77 & 1.02 & 4.5 \\
\hline & & 20 & 4 & 76 & 0.97 & 4.4 \\
\hline & Mean \pm s.d. & $22 \pm 5 \%$ & & & & \\
\hline \multirow[t]{7}{*}{ CN75 } & 1 & 37 & 58 & 10 & 0.81 & 0.4 \\
\hline & & 20 & 5 & 10 & 1.05 & 0.4 \\
\hline & & 14 & $\mathrm{NaN}^{\mathrm{b}}$ & 9 & 1.07 & 0.5 \\
\hline & 2 & 23 & 20 & 16 & 0.90 & 0.8 \\
\hline & & 19 & 11 & 17 & 0.90 & 0.9 \\
\hline & & 10 & 8 & 14 & 1.06 & 0.2 \\
\hline & Mean \pm s.d. & $21 \pm 10 \%$ & & & & \\
\hline \multirow[t]{8}{*}{ CN150 } & 1 & 16 & 3 & 25 & 1.04 & 0.4 \\
\hline & & 20 & 1 & 25 & 1.03 & 0.6 \\
\hline & 2 & 18 & 4 & 46 & 0.94 & 3.4 \\
\hline & & 28 & 17 & 48 & 0.88 & 1.7 \\
\hline & 3 & 23 & 2 & 49 & 0.90 & 4.1 \\
\hline & & 28 & 4 & 50 & 0.88 & 4.5 \\
\hline & & 22 & 4 & 52 & 0.85 & 3.7 \\
\hline & Mean \pm s.d. & $22 \pm 5 \%$ & & & & \\
\hline
\end{tabular}

Abbreviations: CI 95\%, 95\% confidence interval; [N+N], sum of the measured $\left[\mathrm{NH}_{4}^{+}\right]$and $\left[\mathrm{NO}_{2}^{-}\right]$.

${ }^{\text {a Approximate }} \mathrm{NH}_{4}^{+}$oxidation rates were calculated from the change in $\left[\mathrm{NO}_{2}^{-}\right]$and the time elapsed between the first and final timepoints, and may underestimate the actual rate in experiments where the final time point was after all $\mathrm{NH}_{4}^{+}$had been consumed.

${ }^{\mathrm{b}}$ Calculating a confidence interval was not possible for this experiment because only two points were available to calculate the slope.
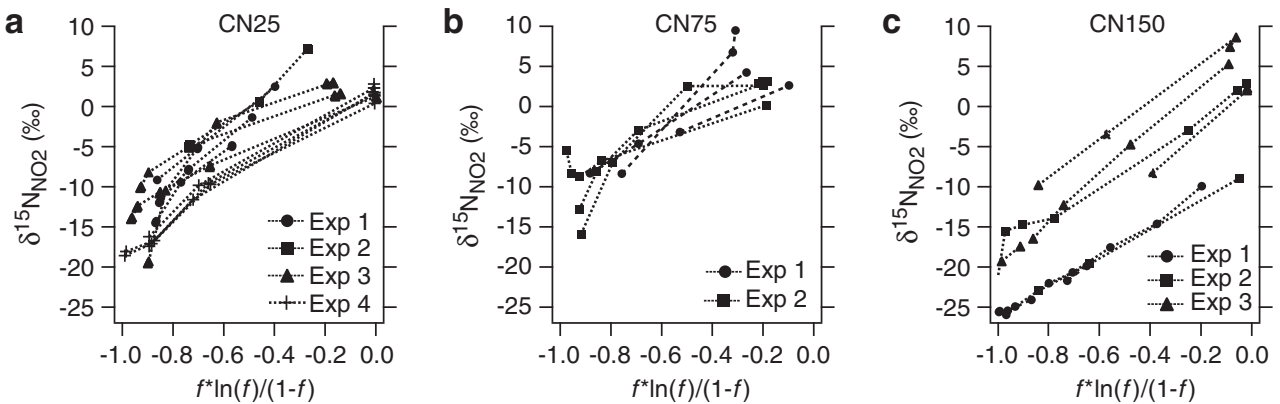

Figure $5 \quad \delta^{15} \mathrm{~N}_{\mathrm{NO} 2}$ during ammonia oxidation in batch culture for the archaeal enrichments (a) CN25, (b) CN75 and (c) CN150. Kinetic isotope effects for ammonia oxidation $\left({ }^{15} \varepsilon_{\mathrm{NH} 3}\right)$ were calculated using linear regression of $\delta^{15} \mathrm{~N}_{\mathrm{NO} 2}$ vs $f * \ln (f) /(1-f)$ as described in the text and are reported in Table 2. $f$ is the fraction of the initial $\left[\mathrm{NH}_{4}^{+}\right]$remaining in the culture.

Further, these results suggest that ATU should not be relied on for complete inhibition of nitrifying activity in environmental samples. For example, nitrification rate measurements in the California Current showed variable $(0-90 \%)$ but on average low levels of inhibition by ATU (mean $35 \%, n=11$ ) consistent with other lines of evidence supporting AOA activity in that study (Santoro et al., 2010). On the other hand, Lam et al., 2009 reported complete inhibition of ammonium oxidation in the presence of $86 \mu \mathrm{moll} \mathrm{l}^{-1}$ ATU in the Eastern Tropical South Pacific oxygen minimum zone. The physiology behind the differential responses of $\mathrm{AOA}$ and $\mathrm{AOB}$ and different environmental communities to this inhibitor is unknown, but could be the result of different metal active sites for enzymes in the ammonia oxidation pathway between the two groups of organisms or differences in metal active sites or affinities of enzymes, or differences in trace metal availability in different field locations.

\section{Nitrogen isotopic fractionation}

Multiple experiments with the three archaeal enrichments suggest a ${ }^{15} \varepsilon_{\mathrm{NH} 3}$ for archaeal ammonia oxidation of approximately $22 \%$. This value falls 
within the reported ${ }^{15} \varepsilon_{\mathrm{NH} 3}$ for bacterial ammonia oxidation of $14 \%$ to $42 \%$ (Mariotti et al., 1981; Casciotti et al., 2003, 2010). Thus, despite genomeinferred differences in the ammonia oxidation pathways of AOA and AOB (Walker et al., 2010), a difference in the magnitude of ${ }^{15} \varepsilon_{\mathrm{NH} 3}$ between these two groups was not apparent.

The physiological reasons for the large range in ${ }^{15} \varepsilon_{\mathrm{NH} 3}$ for both AOA and AOB are unknown, but could result from changes in growth state of the organisms or violations of assumptions associated with using the Rayleigh accumulated product equation to estimate ${ }^{15} \varepsilon_{\mathrm{NH} 3}$ from $\delta^{15} \mathrm{~N}_{\mathrm{NO} 2}$ measurements. Factors to consider include variations in substrate concentration, ammonia oxidation rate and loss of $\mathrm{N}$ to unmeasured pools. Furthermore, unbalanced growth could lead to accumulation of intermediate products in the multi-step oxidation pathway, leading to larger errors involved with characterization of ammonia oxidation as a singlestep unidirectional reaction. At high starting $\left[\mathrm{NH}_{4}^{+}\right]$, expressed ${ }^{15} \varepsilon_{\mathrm{NH} 3}$ values were consistently around 20-22\%o, whereas at low starting $\left[\mathrm{NH}_{4}^{+}\right]$, expressed ${ }^{15} \varepsilon_{\mathrm{NH} 3}$ values were more variable (both higher and lower) and greater uncertainty was involved in their estimation (Table 2). Therefore, no direct relationship can be drawn between $\left[\mathrm{NH}_{4}^{+}\right]$and ${ }^{15} \varepsilon_{\mathrm{NH} 3}$. Similarly, there is no direct relationship between ammonia oxidation rate (or oxidation rate/[ $\left.\mathrm{NH}_{4}^{+}\right]$) and ${ }^{15} \varepsilon_{\mathrm{NH} 3}$ (Table 2).

Although dissolved inorganic nitrogen conservation $\left(\left[\mathrm{NH}_{4}^{+}+\mathrm{NO}_{2}^{-}\right]\right)$was not $100 \%$ in all experiments, the majority of experiments had $\mathrm{NO}_{2}^{-}$ recoveries over $90 \%$ (Table 2), which is within the range reported for pure cultures of AOB (Mariotti et al., 1981; Casciotti et al., 2002). There is likely to be some loss of $\mathrm{NH}_{4}^{+}$because of uptake for anabolic metabolism by AOA and the bacteria in the enrichments, but this sink should be small and consistent across experiments. This process would alter observed ${ }^{15} \varepsilon_{\mathrm{NH} 3}$ values in proportion to the amount of $\mathrm{NH}_{4}^{+}$assimilated and the isotope effect for $\mathrm{NH}_{4}^{+}$ assimilation (4-27\%; (Hoch et al., 1992)). However, we emphasize that this effect is likely to be small and note that relatively high estimates of ${ }^{15} \varepsilon_{\mathrm{NH} 3}$, not low ones, were observed where recovery was low (Table 2). We did not make measurements of $\left[\mathrm{NO}_{3}^{-}\right]$ in the experiments described here, but we have not observed $\mathrm{NO}_{2}^{-}$loss over time and have no evidence that $\mathrm{NO}_{2}^{-}$is further oxidized to $\mathrm{NO}_{3}^{-}$in any of the enrichments.

In addition to variation between experiments, we found evidence for variable ${ }^{15} \varepsilon_{\mathrm{NH} 3}$ during archaeal ammonia oxidation within some experiments, with the greatest ${ }^{15} \varepsilon_{\mathrm{NH} 3}$ expressed at the early stages of growth. This was particularly apparent for CN25 and CN75 enrichments grown at low $\left[\mathrm{NH}_{4}^{+}\right]$ $(<20 \mu \mathrm{M})$, which exhibited a considerable lag phase before the commencement of ammonia oxidation. Variable $\varepsilon$ values have been observed in many other organisms, including denitrifiers (Granger et al.,
2008), methane oxidizers (Templeton et al., 2006), sulfate reducers (Habicht et al., 2005) and nitrite oxidizers (Casciotti, 2009; Buchwald and Casciotti, 2010), and during assimilation of $\mathrm{NH}_{4}^{+}$by heterotrophic bacteria (Hoch et al., 1992) but has not previously been reported in ammonia-oxidizing organisms. We explore two hypotheses that could explain a large apparent isotope effect at the early stages of growth (Figure 6).

The first hypothesis is that, in the early stages of growth in batch culture, diffusion of $\mathrm{NH}_{3}$ and/or $\mathrm{NH}_{4}^{+}$between the growth medium and the periplasm is rapid relative to the oxidation rate ( $R_{\text {diff,NH3 }}$ or $R_{\text {diff,NH4 }}>R_{\text {AMO }}$ ) and enzymatic ammonia oxidation is the rate-limiting step. In this scenario, the enzyme-level isotope effect $\left({ }^{15} \varepsilon_{\mathrm{AMO}}\right)$, plus the equilibrium isotope effect between $\mathrm{NH}_{3}$ and $\mathrm{NH}_{4}^{+}\left({ }^{15} \varepsilon_{\text {eq }}=19 \%\right.$; (Hermes et al., 1985), should dominate the observed ${ }^{15} \varepsilon_{\mathrm{NH} 3}$ early in the experiment. In the later stages of growth, the reaction may become diffusion limited $\left(R_{\text {diff }}<R_{\text {AMO }}\right)$ and the isotope effect for diffusion $\left({ }^{15} \varepsilon_{\text {diff }}\right)$ would dominate. A similar mechanism has been examined for variations in expressed isotopic fractionation during $\mathrm{NH}_{4}^{+}$assimilation by bacteria (Hoch et al., 1992) and marine algae (Pennock et al., 1996), as well as $\mathrm{CO}_{2}$ uptake by algae (Laws et al., 1997) and plants (O'Leary, 1981). Diffusion of $\mathrm{NH}_{3}$ in aqueous solution is estimated to have an isotope effect of $20 \%$ (Hoch et al., 1992), which is similar to the late-stage ${ }^{15} \varepsilon_{\mathrm{NH} 3}$ values we observed. However, this scenario would predict a direct relationship between $\left[\mathrm{NH}_{4}^{+}\right]$ and ${ }^{15} \varepsilon_{\mathrm{NH} 3}$ in experiments starting at different initial $\mathrm{NH}_{4}^{+}$concentrations, which is not observed in our data (Table 2). If anything, we observe larger ${ }^{15} \varepsilon_{\mathrm{NH} 3}$ values at low initial $\left[\mathrm{NH}_{4}^{+}\right]$. Therefore, we reject the hypothesis of diffusion limitation in controlling ${ }^{15} \varepsilon_{\mathrm{NH} 3}$ in these experiments.

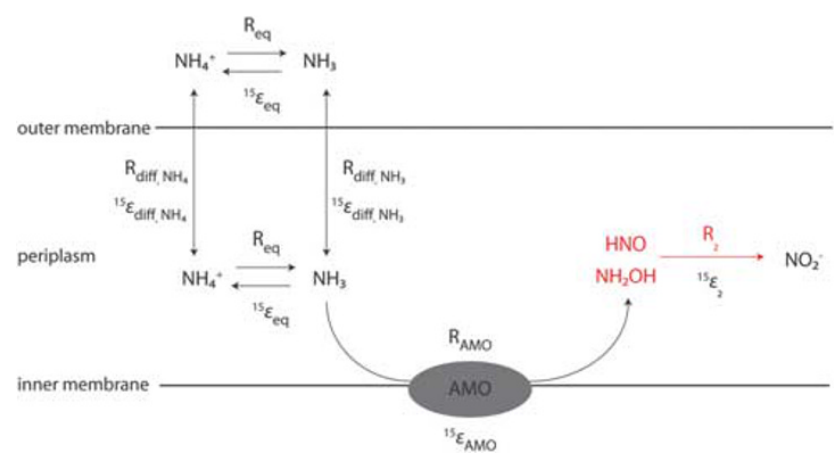

Figure 6 Potential pathways of $\mathrm{NH}_{3}$ acquisition and oxidation by AOA that could lead to a variable kinetic isotope effect $\left({ }^{15} \varepsilon_{\mathrm{NH} 3}\right)$ (Walker et al., 2010). $R_{\text {eq }}$ and ${ }^{15} \varepsilon_{\text {eq }}$ are the rate and equilibrium isotope effect for $\mathrm{NH}_{3} / \mathrm{NH}_{4}^{+}$equilibration, $R_{\text {diff,NH4 }}$ and ${ }^{15} \varepsilon_{\text {diff,NH} 4}$ are the rate and kinetic isotope effect for $\mathrm{NH}_{4}^{+}$diffusion, $R_{\text {diff,NH3 }}$ and ${ }^{15} \varepsilon_{\text {diff,NH3 }}$ are the rate and kinetic isotope effect for $\mathrm{NH}_{3}$ diffusion, $R_{\text {AMO }}$ and ${ }^{15} \varepsilon_{\text {AMO }}$ are the rate and kinetic isotope effect for ammonia oxidation by ammonia monooxygenase (Amo), and $R_{2}$ and ${ }^{15} \varepsilon_{2}$ are the rate and kinetic isotope effect for the second step of the ammonia oxidation pathway. Major uncertainties in the archaeal oxidation pathway are shown in red. 
It has been assumed here that the Amo-catalyzed reaction occurs in the periplasm, as it does in AOB, and that active transport of $\mathrm{NH}_{3}$ or $\mathrm{NH}_{4}^{+}$into the periplasm from the medium does not occur. Genes for putative Amt transporters have been identified in the genomes of both AOB (Arp et al., 2007) and AOA (Hallam et al., 2006; Walker et al., 2010; Blainey et al., 2011) and expression of these genes in environmental samples appears proportional to expression of amo genes (Stewart et al., 2011). At this time it is uncertain whether Amt supplies $\mathrm{N}$ for anabolic metabolism serves a regulatory function (Arp et al., 2007), or supplies substrate to the Amo enzyme. However, if Amt is localized for transport across the cytoplasmic membrane (Andrade et al., 2005), it would be difficult to envision a role for Amt in the ${ }^{15} \varepsilon_{\mathrm{NH} 3}$ variations observed here.

A second hypothesis to explain the withinexperiment variations in ${ }^{15} \varepsilon_{\mathrm{NH} 3}$ is that during early exponential phase growth, the first step of ammonia oxidation proceeds more quickly than the second step $\left(R_{\mathrm{AMO}}>R_{2}\right)$ and an as-yet unknown intermediate $\left(\mathrm{NH}_{2} \mathrm{OH}\right.$ or $\left.\mathrm{HNO}\right)$ accumulates. This intermediate pool would be isotopically depleted relative to $\mathrm{NH}_{4}^{+}$outside the cell, and a second isotope effect would be expressed $\left({ }^{15} \varepsilon_{2}\right.$; Figure 6) resulting in the production of $\mathrm{NO}_{2}^{-}$with a large apparent isotope effect. If the intermediate pool is eventually used up and ammonia oxidation proceeds as a pseudo onestep reaction, the apparent isotope effect should decrease to ${ }^{15} \varepsilon_{\mathrm{AMO}}$ (plus ${ }^{15} \varepsilon_{\text {eq }}$ ) late in the experiment. This hypothesis is consistent with the fact that curvature in the Rayleigh plots was most prominent where long lag phases preceded ammonia oxidation, which may be associated with imbalanced growth early in the experiment. Interestingly, if this hypothesis is correct, the similarity between average ${ }^{15} \varepsilon_{\mathrm{NH}}$ $(22 \%)$ and ${ }^{15} \varepsilon_{\text {eq }}(19 \%$ ); (Hermes et al., 1985) may indicate a small kinetic isotope effect for Amo. Use of the Rayleigh distillation equation with measurements of $\delta^{15} \mathrm{~N}_{\mathrm{NH} 4}$ would get around the potential problem from accumulation of intermediates, although it would still be affected by $\mathrm{NH}_{3} / \mathrm{NH}_{4}^{+}$ equilibration and $\mathrm{NH}_{4}^{+}$transport effects discussed above. At this time there are many additional uncertainties in the archaeal ammonia oxidation pathway (Klotz and Stein, 2008; Walker et al., 2010) including the exact chemical intermediates, the localization of the respiratory enzymes within the cell, and the role of active $\mathrm{NH}_{3} / \mathrm{NH}_{4}^{+}$transport that must be resolved before the mechanisms causing variable ${ }^{15} \varepsilon_{\mathrm{NH} 3}$ can be fully explained.

The ultimate goal of determining species-level isotope effects is to better interpret natural abundance stable isotope ratios $\left(\delta^{15} \mathrm{~N}_{\mathrm{NO} 3}\right.$ and $\left.\delta^{18} \mathrm{O}_{\mathrm{NO} 3}\right)$ in the environment. The average $\delta^{15} \mathrm{~N}$ of marine $\mathrm{NO}_{3}^{-}$is set by the balance of $\mathrm{N}_{2}$ fixation and $\mathrm{N}$ removal by denitrification and anammox (Brandes and Devol, 2002), although nitrification can affect the partitioning of ${ }^{15} \mathrm{~N}$ between dissolved and particulate $\mathrm{N}$ (Wankel et al., 2007). The potential for variable
${ }^{15} \varepsilon_{\mathrm{NH} 3}$ adds an extra level of complexity to the interpretations of $\delta^{15} \mathrm{~N}_{\mathrm{NO} 3}$ in the environment.

Nitrification is also the main determinant in setting the average $\delta^{18} \mathrm{O}$ of marine $\mathrm{NO}_{3}^{-}$(Casciotti et al., 2002; Sigman et al., 2009) and $\mathrm{N}_{2} \mathrm{O}$ (Ostrom et al., 2000; Popp et al., 2002). Determining the oxygen isotope effects for archaeal ammonia oxidation will therefore be an important next step in advancing the use of the dual isotope signatures of $\mathrm{NO}_{3}^{-}$and $\mathrm{N}_{2} \mathrm{O}$ to understand the marine nitrogen cycle.

\section{Conflict of interest}

The authors declare no conflict of interest.

\section{Acknowledgements}

This work was supported by a Woods Hole Oceanographic Institution (WHOI) Postdoctoral Scholar fellowship to AES and the WHOI Ocean Life Institute. We thank Josh Plant and Ken Johnson for the $\mathrm{NH}_{4}^{+}$concentration data from cruise CN107, and Christopher Francis for logistical support during that cruise. Matt McIlvin is acknowledged for expert technical assistance with mass spectrometry. Cornelia Wuchter is acknowledged for assistance with the CARDFISH procedure. Louis Kerr at the Marine Biological Laboratory microscopy facility assisted with the fluorescence micrographs. We thank Stefan Sievert and Matt Johnson for access to equipment in their laboratories. Carolyn Buchwald, Edward Leadbetter and three anonymous reviewers provided invaluable comments on the paper.

\section{References}

Andrade SLA, Dickmanns A, Ficner R, Einsle O. (2005). Crystal structure of the archaeal ammonium transporter Amt-1 from Archaeoglobus fulgidus. Proc Natl Acad Sci USA 102: 14994.

Arp DJ, Chain PSG, Klotz MG. (2007). The impact of genome analyses on our understanding of ammoniaoxidizing bacteria. Microbiology 61: 503.

Balch WE, Fox GE, Magrum LJ, Woese CR, Wolfe RS. (1979). Methanogens-re-evaluation of a unique biological group. Microbiol Rev 43: 260-296.

Bedard C, Knowles R. (1989). Physiology, biochemistry, and specific inhibitors of $\mathrm{CH} 4, \mathrm{NH} 4+$, and $\mathrm{CO}$ oxidation by methanotrophs and nitrifiers. Microbiol Mol Biol Rev 53: 68.

Beman JM, Popp BN, Francis CA. (2008). Molecular and biogeochemical evidence for ammonia oxidation by marine Crenarchaeota in the Gulf of California. ISME J 2: 429-441.

Beman JM, Sachdeva R, Fuhrman JA. (2010). Population ecology of nitrifying Archaea and Bacteria in the Southern California Bight. Environ Microbiol 12: 1282-1292.

Bernhard AE, Landry ZC, Blevins A, de la Torre JR, Giblin AE, Stahl DA. (2010). Abundance of ammonia-oxidizing archaea and bacteria along an estuarine salinity gradient in relationship to potential nitrification rates. Appl Environ Microbiol 76: 1285-1289. 
Blainey PC, Mosier AC, Potanina A, Francis CA, Quake SR, Gilbert J. (2011). Genome of a low-salinity ammonia-oxidizing archaeon determined by singlecell and metagenomic analysis. PLoS One 6: 148-149.

Brandes JA, Devol AH. (2002). A global marine-fixed nitrogen isotopic budget: implications for Holocene nitrogen cycling. Global Biogeochem Cycles 16: 1120.

Brochier-Armanet C, Boussau B, Gribaldo S, Forterre P. (2008). Mesophilic crenarchaeota: proposal for a third archaeal phylum, the Thaumarchaeota. Nat Rev Microbiol 6: 245-252.

Buchwald C, Casciotti KL. (2010). Oxygen isotopic fractionation and exchange during bacterial nitrite oxidation. Limnol Oceanogr 55: 1064-1074.

Casciotti KL. (2009). Inverse kinetic isotope fractionation during bacterial nitrite oxidation. Geochimica Et Cosmochimica Acta 73: 2061-2076.

Casciotti KL, Bohlke JK, McIlvin MR, Mroczkowski SJ, Hannon JE. (2007). Oxygen isotopes in nitrite: analysis, calibration, and equilibration. Anal Chem 79: 2427-2436.

Casciotti KL, Buchwald C, Santoro AE, Frame C. (2011). Assessment of nitrogen and oxygen isotope fraction during nitrification and its expression in the marine environment. Methods Enzymol 486: 253-280.

Casciotti KL, McIlvin MR, Buchwald C. (2010). Oxygen isotopic exchange and fractionation during bacterial ammonia oxidation. Limnol Oceanogr 55: 753-762.

Casciotti KL, Sigman DM, Hastings MG, Bohlke JK, Hilkert A. (2002). Measurement of the oxygen isotopic composition of nitrate in seawater and freshwater using the denitrifier method. Anal Chem 74: 4905-4912.

Casciotti KL, Sigman DM, Ward BB. (2003). Linking diversity and stable isotope fractionation in ammonia-oxidizing bacteria. Geomicrobiology Journal 20: 335-353.

Casciotti KL, Trull TW, Glover DM, Davies D. (2008). Constraints on nitrogen cycling at the subtropical North Pacific Station ALOHA from isotopic measurements of nitrate and particulate nitrogen. Deep Sea Res 55: 1661-1672.

Church MJ, Karl DM, DeLong EF. (2010). Abundances of crenarchaeal amoA genes and transcripts in the Pacific Ocean. Environ Microbiol 12: 679-688.

Clark DR, Rees AP, Joint I. (2008). Ammonium regeneration and nitrification rates in the oligotrophic Atlantic Ocean: Implications for new production estimates. Limnol Oceanogr 53: 52-62.

Coolen MJL, Abbas B, van Bleijswijk J, Hopmans EC, Kuypers MMM, Wakeham SG et al. (2007). Putative ammonia-oxidizing Crenarchaeota in suboxic waters of the Black Sea: a basin-wide ecological study using $16 \mathrm{~S}$ ribosomal and functional genes and membrane lipids. Environ Microbiol 9: 1001-1016.

de la Torre JR, Walker CB, Ingalls AE, Koenneke M, Stahl DA. (2008). Cultivation of a thermophilic ammonia oxidizing archaeon synthesizing crenarchaeol. Environ Microbiol 10: 810-818.

Delong EF. (1992). Archaea in coastal marine environments. Proc Natl Acad Sci USA 89: 5685-5689.

DiFiore PJ, Sigman DM, Dunbar RB. (2009). Upper ocean nitrogen fluxes in the Polar Antarctic Zone: constraints from the nitrogen and oxygen isotopes of nitrate. Geochemistry Geophysics Geosystems 10: Q11016.

Eppley RW, Peterson BJ. (1979). Particulate organic matter flux and planktonic new production in the deep ocean. Nature 282: 677.
Francis CA, Roberts KJ, Beman JM, Santoro AE, Oakley BB. (2005). Ubiquity and diversity of ammonia-oxidizing archaea in water columns and sediments of the ocean. Proc Natl Acad Sci USA 102: 14683-14688.

Ginestet P, Audic JM, Urbain V, Block JC. (1998). Estimation of nitrifying bacterial activities by measuring oxygen uptake in the presence of the metabolic inhibitors allylthiourea and azide. Appl Environ Microbiol 64: 2266-2268.

Granger J, Sigman DM, Lehmann MF, Tortell PD. (2008). Nitrogen and oxygen isotope fractionation during dissimilatory nitrate reduction by denitrifying bacteria. Limnol Oceanogr 53: 2533-2545.

Granger J, Sigman DM, Needoba JA, Harrison PJ. (2004). Coupled nitrogen and oxygen isotope fractionation of nitrate during assimilation by cultures of marine phytoplankton. Limnol Oceanogr 49: 1763-1773.

Habicht K, Salling L, Thamdrup B, Canfield D. (2005). Effect of low sulfate concentrations on lactate oxidation and isotope fractionation during sulfate reduction by Archaeoglobus fulgidus strain Z. Appl Environ Microbiol 71: 3770.

Hallam SJ, Mincer TJ, Schleper C, Preston CM, Roberts K, Richardson PM et al. (2006). Pathways of carbon assimilation and ammonia oxidation suggested by environmental genomic analyses of marine Crenarchaeota. PLoS Biol 4: 520-536.

Hatzenpichler R, Lebecleva EV, Spieck E, Stoecker K, Richter A, Daims H et al. (2008). A moderately thermophilic ammonia-oxidizing crenarchaeote from a hot spring. Proc Natl Acad Sci USA 105: 2134-2139.

Hermes JD, Weiss PM, Cleland W. (1985). Use of nitrogen15 and deuterium isotope effects to determine the chemical mechanism of phenylalanine ammonialyase. Biochemistry 24: 2959-2967.

Hoch MP, Fogel ML, Kirchman DL. (1992). Isotope fractionation associated with ammonium uptake by a marine bacterium. Limnol Oceanogr 37: 1447-1459.

Holmes RM, Aminot A, Kèrouel R, Hooker BA, Peterson BJ. (1999). A simple and precise method for measuring ammonium in marine and freshwater ecosystems. Can J Fish Aquat Sci 56: 1801-1808.

Hooper AB, Terry KR. (1973). Specific inhibitors of ammonia oxidation in Nitrosomonas. J Bacteriol 115: 480.

Hyman MR, Wood P. (1985). Suicidal inactivation and labelling of ammonia mono-oxygenase by acetylene. Biochem J 227: 719.

Johnson KS, Boyle E, Bruland K, Coale K, Measures C, Moffett J et al. (2007). The SAFe iron intercomparison cruise: an international collaboration to develop dissolved iron in seawater standards. EOS Trans Am Geophysical Union 88: 131-132.

Klotz MG, Stein LY. (2008). Nitrifier genomics and evolution of the nitrogen cycle. FEMS Microbiol Lett 278: 146-156.

Konneke M, Bernhard AE, de la Torre JR, Walker CB, Waterbury JB, Stahl DA. (2005). Isolation of an autotrophic ammonia-oxidizing marine archaeon. Nature 437: 543-546.

Lam P, Jensen MM, Lavik G, McGinnis DF, Muller B, Schubert CJ et al. (2007). Linking crenarchaeal and bacterial nitrification to anammox in the Black Sea. Proc Natl Acad Sci USA 104: 7104-7109.

Lam P, Lavik G, Jensen MM, van de Vossenberg J, Schmid M, Woebken D et al. (2009). Revising the nitrogen cycle in the Peruvian oxygen minimum zone. Proc Natl Acad Sci USA 106: 4752. 
Laws EA, Bidigare RR, Popp BN. (1997). Effect of growth rate and $\mathrm{CO} 2$ concentration on carbon isotopic fractionation by the marine diatom Phaeodactylum tricornutum. Limnol Oceanogr 42: 1552-1560.

Ludwig W, Strunk O, Westram R, Richter L, Meier H, Yadhukumar et al. (2004). ARB: a software environment for sequence data. Nucleic Acids Res 32: 1363-1371.

Mariotti A, Germon JC, Hubert P, Kaiser P, Letolle R, Tardieux A et al. (1981). Experimental determination of nitrogen kinetic isotope fractionation: some principles; illustration for the denitrification and nitrification processes. Plant Soil 62: 413-430.

Martens-Habbena W, Berube PM, Urakawa H, de la Torre JR, Stahl DA. (2009). Ammonia oxidation kinetics determine niche separation of nitrifying Archaea and Bacteria. Nature 461: 976-981.

McIlvin MR, Altabet MA. (2005). Chemical conversion of nitrate and nitrite to nitrous oxide for nitrogen and oxygen isotopic analysis in freshwater and seawater. Anal Chem 77: 5589-5595.

McIlvin MR, Casciotti KL. (2010). Fully automated system for stable isotopic analysis of dissolved nitrous oxide at natural abundance levels. Limnol Oceanograph Methods 8: 54-66.

McIlvin MR, Casciotti KL. (2011). Technical updates to the bacterial method for nitrate isotopic analyses. Anal Chem 83: 1850-1856.

Mincer TJ, Church MJ, Taylor LT, Preston C, Karl DM, DeLong EF. (2007). Quantitative distribution of presumptive archaeal and bacterial nitrifiers in Monterey Bay and the North Pacific Subtropical Gyre. Environ Microbiol 9: 1162-1175.

Morris JJ, Kirkegaard R, Szul MJ, Johnson ZI, Zinser ER. (2008). Facilitation of robust growth of Prochlorococcus colonies and dilute liquid cultures by 'helper' heterotrophic bacteria. Appl Environ Microbiol 74: 4530.

Mosier AC, Francis CA. (2008). Relative abundance and diversity of ammonia-oxidizing archaea and bacteria in the San Francisco Bay estuary. Environ Microbiol 10: 3002-3016.

Needoba JA, Waser NA, Harrison PJ, Calvert SE. (2003). Nitrogen isotope fractionation in 12 species of marine phytoplankton during growth on nitrate. Marine Ecol Prog Ser 255: 81-91.

O'Leary MH. (1981). Carbon isotope fractionation in plants. Phytochemistry 20: 553-567.

Olson RJ. (1981). $15 \mathrm{~N}$ tracer studies of the primary nitrite maximum. J Mar Res 39: 203-226.

Ostrom NE, Russ ME, Popp BN, Rust TM, Karl DM. (2000). Mechanisms of nitrous oxide production in the subtropical North Pacific based on determinations of the isotopic abundances of nitrous oxide and dioxygen. Chemosphere-Global Change Sci 2: 281-290.

Pennock JR, Velinsky DJ, Ludlam JM, Sharp JH, Fogel ML. (1996). Isotopic fractionation of ammonium and nitrate during uptake by Skeletonema costatum: implications for $15 \mathrm{~N}$ dynamics under bloom conditions. Limnol Oceanogr 41: 451-459.

Popp BN, Westley MB, Toyoda S, Miwa T, Dore JE, Yoshida $\mathrm{N}$ et al. (2002). Nitrogen and oxygen isotopomeric constraints on the origins and sea-to-air flux of $\mathrm{N} 2 \mathrm{O}$ in the oligotrophic subtropical North Pacific gyre. Global Biogeochem Cycles 16: 1064.

Prosser JI. (1990). Autotrophic nitrification in bacteria. Adv Microb Physiol 30: 125-181.
Pruesse E, Quast C, Knittel K, Fuchs B, Ludwig W, Peplies J et al. (2007). SILVA: a comprehensive online resource for quality checked and aligned ribosomal RNA sequence data compatible with ARB. Nucleic Acids Res 35: 7188.

Purkhold U, Pommerening-Roser A, Juretschko S, Schmid MC, Koops HP, Wagner M. (2000). Phylogeny of all recognized species of ammonia oxidizers based on comparative 16S rRNA and amoA sequence analysis: implications for molecular diversity surveys. Appl Environ Microbiol 66: 5368-5382.

Rusch DB, Halpern AL, Sutton G, Heidelberg KB, Williamson S, Yooseph S et al. (2007). The Sorcerer II Global Ocean Sampling expedition: northwest Atlantic through Eastern Tropical Pacific. Plos Biology 5: $398-431$.

Santoro AE, Casciotti KL, Francis CA. (2010). Activity, abundance and diversity of nitrifying archaea and bacteria in the central California Current. Environ Microbiol 12: 1989-2006.

Santoro AE, Francis CA, de Sieyes NR, Boehm AB. (2008). Shifts in the relative abundance of ammonia-oxidizing bacteria and archaea across physicochemical gradients in a subterranean estuary. Environ Microbiol 10: 1068-1079.

Sigman DM, DiFiore PJ, Hain MP, Deutsch C, Wang Y, Karl DM et al. (2009). The dual isotopes of deep nitrate as a constraint on the cycle and budget of oceanic fixed nitrogen. Deep Sea Research Part I: Oceanographic Research Papers 56: 1419-1439.

Sigman DM, Granger J, DiFiore PJ, Lehmann MF, Ho R, Cane $G$ et al. (2005). Coupled nitrogen and oxygen isotope measurements of nitrate along the eastern North Pacific margin. Global Biogeochem Cycles 19: GB4022.

Spang A, Hatzenpichler R, Brochier-Armanet C, Rattei T, Tischler P, Spieck E et al. (2010). Distinct gene set in two different lineages of ammonia-oxidizing archaea supports the phylum Thaumarchaeota. Trends Microbiol 18: 331-340.

Stein JL, Marsh TL, Wu KY, Shizuya H, DeLong EF. (1996). Characterization of uncultivated prokaryotes: isolation and analysis of a 40-kilobase-pair genome fragment from a planktonic marine archaeon. J Bacteriol 178: 591.

Stephen JR, Chang YJ, Macnaughton SJ, Kowalchuk GA, Leung KT, Flemming CA et al. (1999). Effect of toxic metals on indigenous soil beta-subgroup proteobacterium ammonia oxidizer community structure and protection against toxicity by inoculated metal-resistant bacteria. Appl Environ Microbiol 65: 95-101.

Stewart FJ, Ulloa O, DeLong EF. (2011). Microbial metatranscriptomics in a permanent marine oxygen minimum zone. Environ Microbiol. doi:10.1111/ j.1462-2920.2010.02400.

Strickland J, Parsons T. (1968). A practical handbook of seawater analysis. Fish Res Board Can Bull 167: 71-75.

Teira E, Reinthaler T, Pernthaler A, Pernthaler J, Herndl GJ. (2004). Combining catalyzed reporter depositionfluorescence in situ hybridization and microautoradiography to detect substrate utilization by bacteria and archaea in the deep ocean. Appl Environ Microbiol 70: 4411

Templeton AS, Chu KH, Alvarez-Cohen L, Conrad ME. (2006). Variable carbon isotope fractionation expressed by aerobic CH4-oxidizing bacteria. Geochimica Et Cosmochimica Acta 70: 1739-1752. 
Urakawa H, Martens-Habbena W, Stahl DA. (2010). High abundance of ammonia-oxidizing archaea in coastal waters, determined using a modified DNA extraction method. Appl Environ Microbiol 76: 2129.

Venter JC, Remington K, Heidelberg JF, Halpern AL, Rusch D, Eisen JA et al. (2004). Environmental genome shotgun sequencing of the Sargasso Sea. Science 304: 66-74.

Walker CB, de la Torre JR, Klotz MG, Urakawa H, Pinel N, Arp DJ et al. (2010). Nitrosopumilus maritimus genome reveals unique mechanisms for nitrification and autotrophy in globally distributed marine crenarchaea. Proc Natl Acad Sci USA 107: 8818-8823.

Wankel SD, Kendall C, Pennington JT, Chavez FP, Paytan A. (2007). Nitrification in the euphotic zone as evidenced by nitrate dual isotopic composition:
Observations from Monterey Bay, California. Global Biogeochemical Cycles 21: GB2009.

Ward BB. (2002). Nitrification in aquatic environments. In: Capone DG (ed). Encyclopedia of Environmental Microbiology. John Wiley \& Sons: New York, pp 2144-2167.

Ward BB, Olson RJ, Perry MJ. (1982). Microbial nitrification rates in the primary nitrite maximum off Southern-California. Deep-Sea Res A-Oceanograph Res Papers 29: 247-255.

Wuchter C, Abbas B, Coolen MJL, Herfort L, van Bleijswijk J, Timmers $\mathrm{P}$ et al. (2006). Archaeal nitrification in the ocean. Proc Natl Acad Sci USA 103: 12317-12322.

Yool A, Martin AP, Fernandez C, Clark DR. (2007). The significance of nitrification for oceanic new production. Nature 447: 999-1002.

Supplementary Information accompanies the paper on The ISME Journal website (http://www.nature.com/ismej) 